Abstracta Iranica Iranica

Revue bibliographique pour le domaine irano-aryen

Volume 27 | 2006

Comptes rendus des publications de 2004

\title{
« An early Seljuq silver bottle from Siberia ». Muqarnas, XXI (2004), pp. 255-265.
}

\section{Rocco Rante}

\section{(2) OpenEdition}

1 Journals

\section{Édition électronique}

URL : http://journals.openedition.org/abstractairanica/6153

DOI : 10.4000/abstractairanica.6153

ISSN : 1961-960X

Éditeur :

CNRS (UMR 7528 Mondes iraniens et indiens), Éditions de l'IFRI

\section{Édition imprimée}

Date de publication : 15 mai 2006

ISSN : 0240-8910

\section{Référence électronique}

Rocco Rante, « «An early Seljuq silver bottle from Siberia ». Muqarnas, XXI (2004), pp. 255-265. », Abstracta Iranica [En ligne], Volume 27 | 2006, document 248, mis en ligne le 02 janvier 2007, consulté le 25 septembre 2020. URL : http://journals.openedition.org/abstractairanica/6153 ; DOI : https:// doi.org/10.4000/abstractairanica.6153

Ce document a été généré automatiquement le 25 septembre 2020.

Tous droits réservés 


\title{
« An early Seljuq silver bottle from Siberia ». Muqarnas, XXI (2004), pp. 255-265.
}

\author{
Rocco Rante
}

1 Boris Marshak fait l'analyse détaillée d'une bouteille en argent conservée au Musée de l'Ermitage de Saint Petersbourg. Il souligne d'abord l'importance de sa provenance, la Sibérie (précisément la partie basse du basin de l'ob). L'objet a transité par «la route des fourrures » qui, comme celle de la soie, passait au nord des montagnes Tianshan.

2 L'A. analyse minutieusement chaque partie de l'objet: d'abord les inscriptions en arabe, gravées sur le col et la panse de l'objet, utilisant des formules de souhait répétitives à des époques déterminées. Il examine ensuite les décorations végétales ornant le corps de l'objet, en particulier le fond de l'unique inscription en nasHī et celui des trois médaillons formant l'inscription en caractères coufiques qui court autour du corps de la bouteille.

3 L'A. évoque ensuite l'importance des échanges, dans les formes et le décor, entre les ateliers de l'est du monde iranien et ceux de l'ouest, entre le $8^{\mathrm{e}}$ et le $11^{\mathrm{e}} \mathrm{s}$., avec des références au $13^{\mathrm{e}} \mathrm{s}$. Mais à partir de cette époque les thèmes décoratifs changeront considérablement.

$4 \quad$ L'A. croise l'analyse des inscriptions avec celle du décor pour dater l'objet de la fin de la période seljukide et identifie les influences dont il résulte.

\section{INDEX}

Thèmes : 5.1. Monde iranophone 
AUTEURS

ROCCO RANTE

IFRI - Téhéran 